\title{
昲 咅
}

鋼 の 水 素脆 化 (1)

田村 博** 石 原 政 男***

\section{Hydrogen Embrittlement of Steel*}

By Hiroshi Tamura** and Masao Ishiwara***

\begin{tabular}{|l|l|}
\hline I. 猪 目 \\
II. 鋼中の水素の挙動 \\
III. 水素脆性の一般的性質 \\
$\left.\begin{array}{l}\text { IV. 遅机破買 } \\
\text { V. 水素脆化理論 } \\
\text { VI. 結 㝘 }\end{array}\right\}$ 次 号 \\
\hline
\end{tabular}

\section{I. 緒言}

鍋の水素脆化は吸収水素のために引張強さや硬さには 目立った変化がなくして伸びや较りなどの延性が著しく 低下する現象として一般には知られている。またてれら に関連した現象には鋼材の白点や酸洗いなどによる脆化 や溶接部の銀点, 線状組織, 気孔や割れなど数多くがあ る.

水素脆化は勿論鋼以外にも $\mathrm{Ni}, \mathrm{Cu}, \mathrm{Ti}, \mathrm{Zr}, \mathrm{U}$ など多 くの金属に起るが，その脆化の機構は鋼の場合とは一般 に異なるものと考元られている：ところで龬への水素脆 化の問題はむち万ん古くから研究が行なわれているが, 木当に注目され始めたのは米国であ第 2 次大戦中に電気 メッキした高張力銅中の水素の存在で航空機に多数の事 故が起って以来の比較的最近のことである゙. この点は 鋼の脆性破壊の研究が米国の溶接船の損賃以来盛んにな った点とその経緯が類似していて誠に興味深い.

わが国では最近とくに高張力鋼の溶接部の低温制れや プロパンタンクで起った硫化水菜による腐食割れで関 連して，䤱の水素脆化の問題が最近にわかにクローズア ップされてきており，てれらに関連した研究が数多く行

* 原稿受付, 昭和39年 1 月 29 日

** 正只, 船舶技術研究所 Member, Ship Research Institute

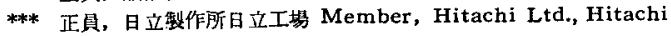
Works
なわれ一般の関心す著しく高まっている，現在ではこの 鋼の水素に上るいわゆる遅れ破壊*が溶接構造物の使用 中の破壊事故例の中に，疲労やクリープとともに長期使 用後の事故として重要な役割を占めている32.

そこで本文では鋼の水素脆化に関する文献を概観し， 従来の研究を展望するととを試みた訳であるが，で存知 のとおりとの種の論文は実に膨大な数にのぼっており， これらをすらさず挙げることはもちろん不可能であるの で主として比較的新しいものについて触れるてとにし， 足りない点については最近交献のリストあ取繹められて むいる゙し，また本文の随所に揭げた主要な論交**によ って不備を補なわせて戴きたい。

\section{II. 鋼中の水素の挙動}

鋼之水素の関係洁すでに岡田教授 ${ }^{5}$, Cotteri116) その ほがー15)により詳細に取縟められている.

\section{II-1 溶解, 吸収}

水素は溶鋼中にもかなり存在し，鐝塊のふくれや白点 などを作りやすい，またアーク溶接では主として被覆剂 中の水分が原因で多量の水素が溶接金属中に侵入し割机 や気孔を作るととはよく知られている

一般に水菜が䤾中に均一溶解する過程としては主とし て i) 吸着 (adsorption) ii) 溶解または吸収 (absorption or occlusion) および iii) 拡散 (diffusion) の三つ の現像が考えられる．液体でも固体中でも鋼中に水素が 入るためには分子状では困難で，原子状またはイオン状 でなり枦ならないとむ言われている，水素吸収の過程 こしては水蒸気や水化物の解離が重要であるが, 電解反 応で原子状水素が活性化またはイオン化されて鋼中に滲 透する現象がある，後者の現象は酸性水溶液中の陰極電

\footnotetext{
* 詳細は次号参照

** たとえば㕕考文献 $1,4,6,13,14,15$ などにすでによくまとられて いる.
} 


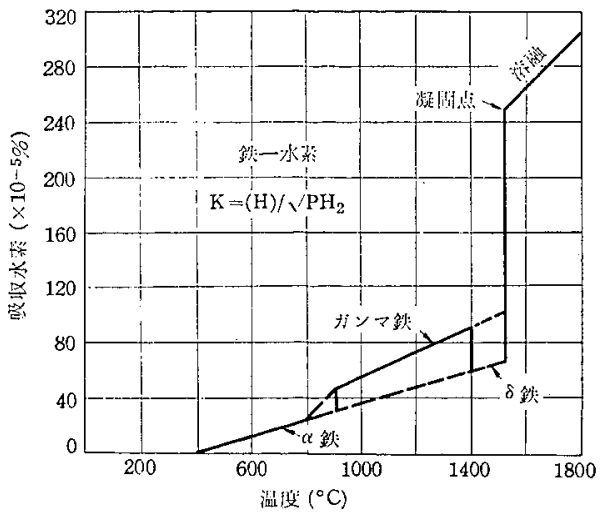

图-1 鉄中の水素の溶解度の温度変化 (C.A. Zapffe)

解により鋼中に水素添加する方法が水䒺脆化の研究に用 いられていることや鍍金や水洗の際の水素吸収》天然ガ スとの接触における硫化物腐食割れ2゙などがこの範疇に 属する.なお鋼中に水素を吸収させる方法にはこの電解 によるほか，300 350 ${ }^{\circ} \mathrm{C}$ 程度の高圧下で行なう方法 ${ }^{19)}$ や $1100 \sim 1200^{\circ} \mathrm{C}$ の高温中に湿った水素を入れて加熱す

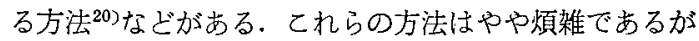
水素が鋼の中までよく入るといわれる。

鍋中の水菜の溶解度は温度とともに図一1の上うに変 化する， $a$ 相加ら $r$ 相に移る際溶解度は著しく増大 し，また溶融点では $r$ 相の約 2 倍に上昇する*.なお図 -1の上うに溶解度が温度の增加とともに增加するのを endothermic な現象, 逆佉減少するのを exthothermic な現象と呼ぶ：ただ図一1は 1 気压の場合で，たとえば 水素分圧が $1 \mathrm{mmHg}$ まで減ると $900^{\circ} \mathrm{C}$ の時の水素の溶 解度が $4 \mathrm{cc} / 100 \mathrm{~g}$ 加ら約 $0.5 \mathrm{cc} / 100 \mathrm{~g}$ まで減少する. すなわ方一般に水素の溶解度 [H] は次の Sieverts の 平衡法則に示すと㧍り，水䒺分圧 $p_{\mathrm{H}_{2}}$ の增加とともに 增大する。

$$
K=[\mathrm{H}] / \sqrt{{\overline{\mathrm{H}_{2}}}_{2}}
$$

平衡恒数 $K$ の値については Chipman と Fontana ${ }^{22)}$ その他により求められている.

鋼中に溶解している水素, 温度および水素圧の関係は 次式で与えられる6).

$$
S=S_{0} \sqrt{p_{\mathrm{H}_{2}}} \exp (-Q / 2 \mathrm{RT})
$$

$S: \mathrm{H}_{2}$ の溶解度 $S_{0}$ : 常数 $p_{\mathrm{H}_{2}}: \mathrm{H}_{2}$ 分代

$Q:$ 溶解熱, カロリー/1瓦モル水素, $R:$ ガス常数 $T:$ 絶対温度

指数項の 2 は $\mathrm{H}_{2}$ が原子状で溶解していることを表す. 同じく $\log$ で書き直すと

* 最近鉄中の水素の最大溶解点が $2450^{\circ} \mathrm{C}$ に見られ，䄪 $40.5 \mathrm{cc} / 100$ grであったことがフームュ鉄について浿定されている21．

$$
\begin{aligned}
& \log S=\log S_{0}+0.5 \log p-\frac{Q}{C T} \\
& C: \text { 常数 }
\end{aligned}
$$

溶解熱は $\log S$ と $1 / T$ の直線関係から求めることがで きる.同じくPhragmén により次式で示される29).

$$
T=\frac{300-0.062 p}{\log p-2 \log x_{1}+3.60}
$$

ここで $x_{1}$ は溶解水素 $(\mathrm{cc} / 100 \mathrm{~g}), T$ は温度 $\left(T^{\circ} K\right)$, $p$ は圧力である. 水素ガス化は溶解水素一定の熱力学的 平衡のもとでは温度の減少に伴い增加する，たとえば格 子中に溶解する $5 \mathrm{cc} / 100 \mathrm{~g}$ の各温度における水素印は 表一 1 のごとくなる.

表一1 各温度における水素王一溶接水素量 $5 \mathrm{cc} / 100 \mathrm{~g}$ (Kazinczy) $)^{23)}$

\begin{tabular}{r|r|r|r|r|r}
\hline \hline 温 度 $\left({ }^{\circ} \mathrm{C}\right)$ & 600 & 300 & 200 & 100 & 20 \\
\hline 水菜压 (気压) & 17 & 880 & 4,080 & 10,870 & 17,500 \\
\hline
\end{tabular}

なお鋼中の割れや気孔などに入っている水素圧は(2.4) 式で与えられた水素濃度および温度のもとで平衡を保っ ている. 空洞中の水素圧が平衡圧加ら変ってくると空洞 中に水素が出入りしてくる.もし空洞の比容積 $(v)$ がわ かっていれば，その中に含まれている水素量 $x_{2}(\mathrm{cc} / 100$ g) は次式から求めることができる ${ }^{23)}$.

$$
x_{2}=\frac{p v}{T} \cdot \frac{34.8}{1+0.0006 p}
$$

图一 2 に気孔中の各温度における水素量之水素生の関係 の 1 例を示す ${ }^{23)}$.

さらに鋼は純粋な水素ガスはもちろん，水蒸気乞のほ 加和水素を吸収する，従って溶解する水素量は一般 には水素ポテンシ アルにより決ま る. 水素ポテンシ アルとは所定の反 応が進行する間溶 解しょうとする水 素の水蒸気䎲対す る制合で24,25), 屯 ちろんとの值が高 いほご吸収水素は 多くなる。実際の アーク溶接などで はこの水素ポテン シァルの増大によ り, 先に示した溶 解度以上の水素を 吸収していると見 てよい。 また水素

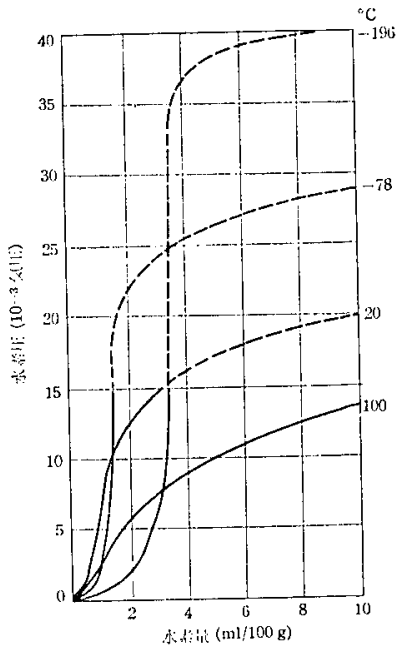

図一 $220^{\circ} \mathrm{C}$ で 0.005 容積 $\% の$ 気 孔中の水素量上水素圧の各温度に 抬ける関係 (Kazinczy) ${ }^{23}$ ) 
ポテンシァルは一般に酸素分王が小さいはど大きい.

な打水素の溶解度は塑性変形その他に上り著しく影響 される.一般には変形が大なるはど大きい26).

\section{II-2 吸着}

鋼亡水秉の反応ではしばしば吸収のほかに段着（adsorption）を考虑しなければならない6)，吸着上は鋼表面 にガスが㠜結して分子程度の薄小層を形成する現象で多 くの場合ガスは吸着と吸収の両方の状態で存在してい る*. Fe や Ni のような endothermic な吸収の場合は 単位当りに吸着する水素ガス量と王力の間には与えられ た温度のもとで一定関係がある．Fast圤ばスが金属中 を浸透する過程を次のように説明している。先ず金属表 面に吸着した尿中のガスが解離し，真の溶解ガスに移動 㹡散し，反対側の吸着層に移動し再び分子状に結合す z.

一般に鋸表面を形成している原子の結合性は非対称性 であるから必ず飽和していない部分ができている. 水素 ガス分子は鋼表面に衝突した際にその未館和部分に凝結 しようとする．この場合の吸着に関与する表面層の範国 は $10^{-8} \mathrm{~cm}$ 程度とあ言われており, ガス分子の径と比 ベればすちろんごく小さい，そこで水素ガスが吸着する 場合の層の厚さはせいぜい 1 分子以下である，水素がス のような 2 原子ガスの場合牥ルゴンや $\mathrm{CO}_{2}$ などと異 り, 分子よりむしろ原子吸着として考えるべきで, 絬局 $\mathrm{H}_{2} \rightarrow 2 \mathrm{H}$ の解離が銅表面に起るものと思われる.この場 合同時に外代と平衡するため表面からはガスが絶えず蒸 発するから，との相反する雨者の合成されたものがいわ ゆる吸着現象としてあらわれるわけである。

吸着水素量はまた圧力の平方根に比例し, 温度の增加 に反比例する，すなわち低圧では吸着は不完全で，また $1000^{\circ} \mathrm{C}$ のよな高温では吸着層中の水素濃度は低く， 鋼中への滲透に多くの時間を要する．以上は主として物 理吸着といわれる屯ので, $-100^{\circ} \mathrm{C}$ 以上の雾囲気では化 学吸着あるいは活性吸着と呼ばれる現象*が加わるため このように単純ではなく，てれらがいろいろの温度で起 る鋼と水素の反応のとくに初期段階に不可欠な受因とな る訳ある。

\section{II-3 拡散}

拡散は一般に（i）格子間，(ii）粒界，(iii) 転位や空 孔を媒介として行なわれるが，水素の場合はこのうちと くに格子間拡散が重要である。とれは拡散の難易が一般 に相互原子の格子常数あるいは外豰電子の相対的大きさ の相違で決まるからである．水素原子の大きさが鉄原子

* この状態をとくに Sorption と呼ぶ.

* 物理吸着の可逆的であるに対して, とくに温度に対して非可逆的. これらについては Smith の著書25゙に詳しい。
のそれに比べてきわかて小さいことは常温における水素 の拡散にきわめて好都合である. いっ仿う水素の拡散速 度は単結晶と多結晶で变らないとされる。すなわち結盟 粒界が水素の拡散を妨げることがあっても決して促進し ないことによると説明されるが，この解釉は必ずし屯当 を得ていない.

水素の拡散の問題は熱伝導の式と類侧して表わせる. すなわち Fick の第2法則にしたがえば

$$
\begin{aligned}
& \frac{\partial c}{\partial t}=D \frac{\partial^{2} c}{\partial x^{2}} \\
& \text { ここで } c: \text { 水菜濃度 } \\
& t: \text { 時間 } \\
& x \text { : 水素が拡散する方向に測った距離 } \\
& D: \text { 鍈中の水素の拡散恒数 }
\end{aligned}
$$

桩散恒数 $D$ は温度により変化する.いま各温度で奏験 して $D$ を求めると， $\log D$ 乙 $1 / T(T$ は絶対温度) は 真線関係亡なる. 古なわち一般に次の形であらわせる.

$$
D \doteq C e^{-Q / R T}
$$

$R$ はガス常数で，これらから活性化エネルギー $Q$ が 実験的に求まる.

鍴中の水素の㹡散恒数の測定は数多くの人々によって 行なわれている. Sykes は $\alpha$ 鉄および $r$ 鉄中の水素の拡 散恒数として次式を与えている.

$$
\begin{aligned}
& D\left(\mathrm{~cm}^{2} / \mathrm{sec}\right)=7.6 \times 10^{-4} e^{-1150 / T}(a \text { 鉄 }) \\
& \mathrm{D}\left(\mathrm{cm}^{2} / \mathrm{sec}\right)=1.5 \times 10^{-2} e^{-1150 / T}(r \text { 鉄 })
\end{aligned}
$$

Stross と Tomkins は $200^{\circ} \mathrm{C}$ 以上の值として次式を 示している1).

$$
D\left(\mathrm{~cm}^{2} / \mathrm{sec}\right)=8.8 \times 10^{-4} e^{-3050 / R T}
$$

しかし以上の多くの計算㯰は高温では一致するも低温 では大きい差がある.たとえば $25^{\circ} \mathrm{C}$ の值は $10^{-9} \sim$ $10^{-5} \mathrm{~cm}^{2} / \mathrm{sec} の$ 範围にばらついている*. また高温の式 加ら外插すると低温の值は一般に実際より低く出るとむ いわれている゙.

Hobson は最近 $2 \frac{1}{2} \mathrm{Ni}-\mathrm{Cr}-\mathrm{Mo}$ 鎆を用い, $-78 \sim 200$ ${ }^{\circ} \mathrm{C}$ の温度䇥囲の水素の拡散恒数を測定している ${ }^{27)}$. 拡 散恒数 $\log _{10} D$ と温度 $1 / T$ の関係をしらべると図一 3 のごとく, 高温加ら $125^{\circ} \mathrm{C}$ までの值は理諭式と一致す るが，乙の点を境に勾配が変化し，厂鉄中の水素の拡散 恒数と同じ勾配を示す.そして約 $-10^{\circ} \mathrm{C}$ でまた最初の 勾配に戻る. Hobson はこの温度筑囲の搪散恒数として 次式を与えた.

$$
D\left(\mathrm{~cm}^{2} / \mathrm{sec}\right)=1.82 \times 10^{-2} e^{-6075 / T}
$$

な打拡散が原子状で起ることは衆知の事実であるが, Bastien によれば陽イオンの形で入ると云われる ${ }^{12,15)} フ^{\circ}$

* 跌および極軟銅の 1 例として $D_{20}{ }^{\circ} \mathrm{C}-(9.1 \pm 1.5) \times 10^{-7} \mathrm{~cm} 2 / \mathrm{sec}$ を得ている26). 


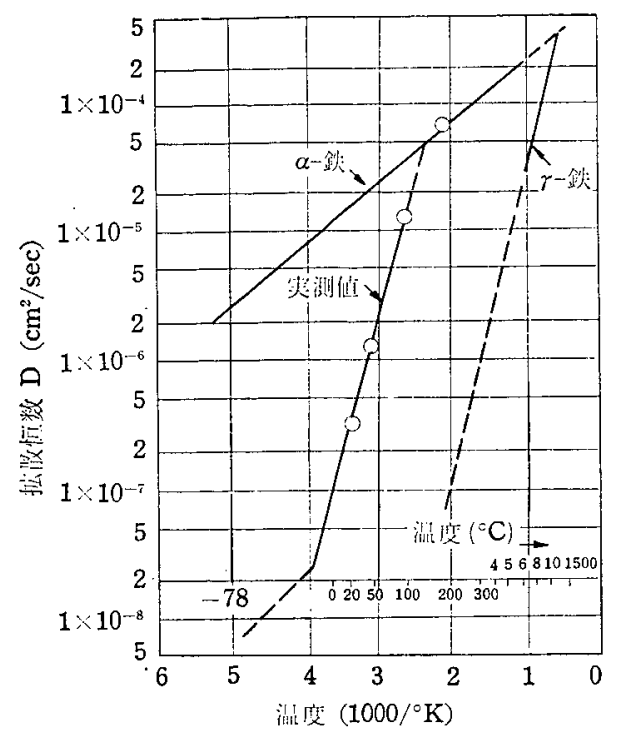

图一 $3 \mathrm{Fe}$ 中の $\mathrm{H}_{2}$ の拡散速度計算值と実測值 ${ }^{27)}$

ロトンの原子間距離は $10^{-13} \mathrm{~cm}$ のオーダーで格子のそ れ $\left(10^{-8} \mathrm{~cm}\right)$ に比してさらに小さい，最近 Darmois も 水素の拡散が少くも部分的にはプロトンの形で行なわれ るという証拠を挙げている.

\section{II-4 鋼中における水素の位置}

鋼における水素の作用を知るには，鋼中におけるその 状態と可能な位置を知る必要がある，水素のような軽い 原子の結鼠中の位置を決定するには普通 X線や電子線で なく，質量のきわめて重い中性子線（電子の約 2,000倍） の回折が用いられる ${ }^{28)}$ 。これまでの実験事実に上れば， 水素は原子状態で鋼中に拡散することおよびての吸収は 侵入型として格子に位置しているととがわかっている.

ただその溶解度から簡単に計算してもせいぜい $10^{3}$ 個* の $\mathrm{Fe}$ 原子付対して水素原子 1 個が存在する程度である ので格子常数の変化も小さいし，その固溶元素としての 影響も少ないと想像される，ところが水素が炭素や空素 などの他の侵入型元素之同じく䎐位と作用して少なから ぬ影響を与えるととが実験的にも数多く知られている $29,30)$.

鋼中の水素の挙動を扱ったすのには D.P. Smith の詳 しい研究25)がある. 彼が提唱している割目理論（rift hypothesis) ${ }^{6)}$ の中でる水素と鋼の反応て実験的影響索 すべて格子欠宿として説明している。すなわち鋼のよう な endothermic occlusion では水素の溶解は必ず格子 が (i) 機械歪 (ii) 熱膨脤（iii）吸収過程自身の上うな 徰で広がった領域に起るということでてれが彼の理論の 基本的概念でもある. Smith はまた鐥が変形すると歪応

\footnotetext{
* Zappfe の部算では $10^{4} \sim 10^{5}$ 個
}

力幻配ができる結果イオンと電子に作用する力が妨げら れるから，奀で誘起した割目は大きいイオン化力を持っ た領域であるとしている，そこで彼は水素が原子として でなく陽子として存在していることを提唱している訳で ある。な抗のように Smith は endothermic な金属に 水素が真の侵入固溶体を作る点に疑問を持っており，こ の割目理論で問題を処理しようとしているが，ての仮説 はまったく定性的で現在のとてろあまり受入れられてい ない，水素の結昆学的な位置についてはいろいろ実験で 確められている. Azou と Plusqullec ${ }^{15.31}$ はアムコ鉄の 単あるいは多結晶を水素処理した試験片に(110)，(112)， (222)(123)面の反射あるいは焦光 X線検查を行なった結 果，(112）面に相当するバンドまたは斑点が明らかに増 加することを認めている，ての広がりは水素除去には十 分だが，鉄格子の回復には低過ぎる程度の真空焼鈍で消 えた. Bastien ${ }^{12.15)}$ はとれらの結果から室温では水素は 四面体の侵入位置の (112) 面海択的に集まるととを主 張しててれが彼の水䒺脆化理論の基本となっている. 詳 しくはV章で改めて述べる.

\section{II-5 結晶欠陥の影腤}

鋼中には飽和以上の水素が含まれるとの実験事実も多 く，塑性変形なぞ受けるとその量はさらに増加する。乙 れらの溶解度を超える多量の水素証鋼中の種々の久陥中 に偏析する訳であるが，乙の場合に水素のとる形は欠陥 の大きさによって異るすのと想像されている.すなわち 空孔や転位などの小欠陷中にはプロトンとして，転位の 集積，副構造部分や粒界など中程度の大きさの欠陥には 原子状として，気泡，ふくれおよび割れなどの大欠陥中 には分子状として存在すると考えるのがごく自然であ る15).

鋼中の水素之結昆欠陷の密接な関係については最近の いろいろの実験的研究でしだいに明らかになりつつあ る.たとえば比較的短時間の添加により多量の水素が鋼 表面近くに偏在することから結晶内の種々のタイプの空 孔（vacancy）がその主要な役制を演じているととが立 証されている.

電解で水菜を加える時, 金中で止めて再添加すると異 常なほど多量に水素を吸収するととがある゙1)．乙れは電 解添加中は格子欠陥の水素江対する作用は強くないが， 中止したのち水素が格子久宿に入るので吸収がさらに可 能になる ${ }^{30)}$.

鎝中の水素の挙動を知る手段としてしばしば内部摩擦 が測られているが32-34)，水素による内部摩擦の增加の原 因として $K_{\dot{e}}$ は水素と転位の相互作用についての説明を 与えている゙5).

水素がCや $\mathrm{N}_{2}$ と同様その侵入型元素として鋼の降伏 
点現象に関係する. 水菜の降伏点効果は約 $-120^{\circ} \mathrm{C}$ 以 下で起るがこれは転位の周りに水素が疑結するととで説 明される12. Aeller が転位の周りの水菜の䨌团気につい て求めた転位之水素の結合エネルギーは約 $0.1 \mathrm{eV}$ 程度 でCや $\mathrm{N}_{2}$ のそれに比べてきわめて小さく，とても室温 で転位を捉えることができないとしている。すなわち室 温での転位や粒界が水䒺を捕捉することの説明は未だ明 らかでない25.

Wiener と Gensamer ${ }^{34)}$ は内部摩摖の測定などをもと にとれに反論を与えている．なお現在多くの研究者によ って支持されている水素脆化の機構*の説明のすべてが, 鋼中の転位などによる微小久宿の存在あるいはそれらと 水素の相互作用を基本としていることは, 結晶欠陷と水 素の関係について今後さらに多くの観察が得られること が早急に望まれる。

\section{III. 水素脆化の一般的性質}

\section{III-1 静的強度}

鋼の機械的性質に及ぼす水素の影響はいろいろの研究 者により取繹められている5,12,15,23,36,37). ただし使用龬 材の種類や試験方法の相違などにより若干の食い違いむ ある. 弾性的特性には大きい変化がない38，ヤング率は 变らない23).ただし Vaughan らの実験胡では軟鋼の比 例限㤎 $10 \mathrm{cc} / 100 \mathrm{~g}$ の水素で $13.8 \mathrm{ton} / \mathrm{in}^{2}$ 加ら $12.7 \mathrm{ton} /$ $\mathrm{in}^{2}$ まで減少した，降伏点屯例外を除き但下しない19,23, 32,36-43). 降伏現象には著しい影響を与元る．水素添加 後 2 分以内試験した 場合上部抢よび下部降 伏点が明瞭にでない16, 40). その後の室温放置 で再び回復する.図一 4 にその 1 例を示した $36,40)$. 降代侸対する水 素の影響は前述の転位 と雾囲気とを引き離す 特の活性化エネルギー

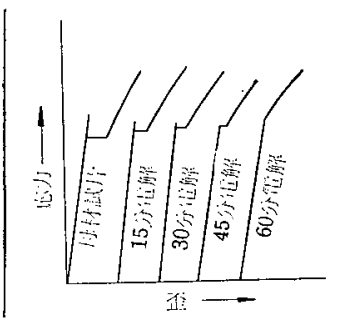

図一4 水菜添扣による降伏 点の消失の様相 ${ }^{36}$
に関伱があるといわれる44)。

引張強さに対する影響は一般にはないるのと見られて いるが，かなり相違した実験例も見られる．たとえばC 量を種々変えた 6 種の炭素䤱について調べた Herres の 結果では明らかに低下が認められている. Hobson と Sykes は明らかに最大応力を越えネッキングを起すまで 水素は真応力一雨曲線の形を变えないと云っている（図 -5 ).

しかしいっぼう破壊の際の真の破断応力は $0.1 \% \mathrm{C} に$
つての Shadburn ¿ Marsall ${ }^{37}$, $0.3 \% \mathrm{C}$ 鋼につい ての Sims, Moore および Williams 37), 各種炭素鋼江 ついての Herres $p$ Bastien $b$

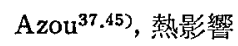
部についての Cottrell の結果 ${ }^{10,46)}$ などすべて水素に より低下してい る. 拡散水素は時 効日数と乞もに低 下するが，水素濃 度に比例して最大 応力は下る。なお 硬さは水素 $10 \mathrm{ml} /$ $100 \mathrm{~g}$ でも変らな (23). しかし加工 硬化曲線の傾斜の 增加がロックエル

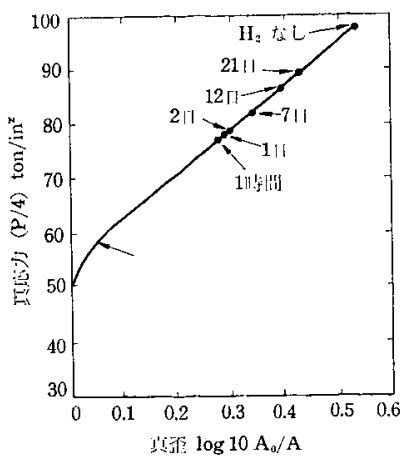

図一5 水素を充渾させた $3 \% \mathrm{Cr}$ Mo 鋼を種々の期間空中に放置 したのちの真応力一霆曲線 (Hobson Sykes)

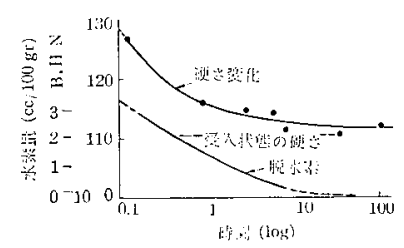

図一6 時間仁よる硬さの減少之水 素の逸脱
$\mathrm{B}$ で 7 程度の増加を伴なったとの報告むある16)。また図 -6では硬さが水素の逸脱とともにやや低下している.

いっぽう水素の影響は伸びや絞りの低下に最む顕著で 古る(図一7 $)^{6,37,40)}$. 一般に水素量と延性は逆比例す $ろ^{37}$. $0.3 \% \mathrm{C}$ 鋼についての Sims らの結果! (図-8) では，約 $0.8 \mathrm{cc} / 100 \mathrm{~g}$ まで延性は急減するがそれ以上。 では低下は徐々であった．乙の傾问は鋼種により相違す $ろ^{37)}$. Sims らの結果では $5 \mathrm{cc} / 100 \mathrm{~g}$ まで隇少しそれ以

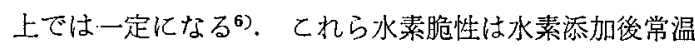
放置により延性が回復する．図一 9 は水素の時間と乞も に放出される傾向を示した.すなおち常温での水素の影

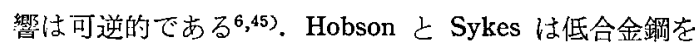
室温で21日間执いた後85〜90\%の回復を認めた。

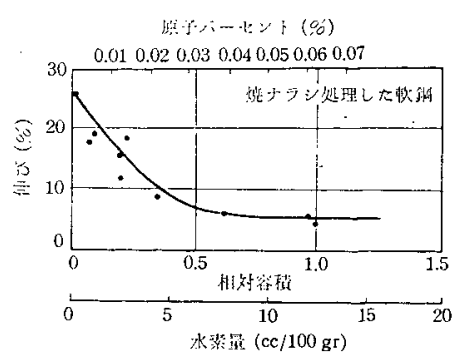

図一７水素添加による伸びの減少（室 温低速丕試験)(Sims, moore-williams) 


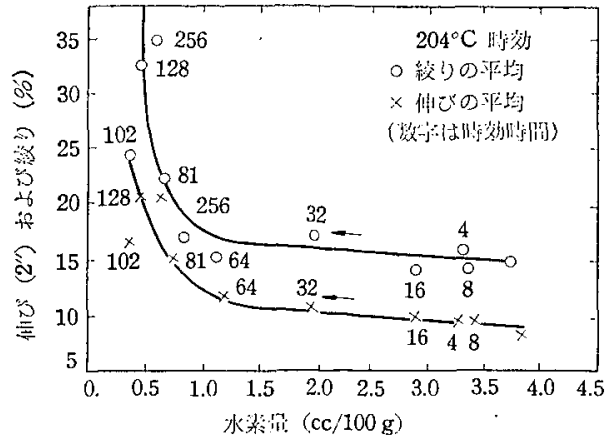

図一8 時効した中炭素鋼の水菜量と延性の関係 (Sims b)

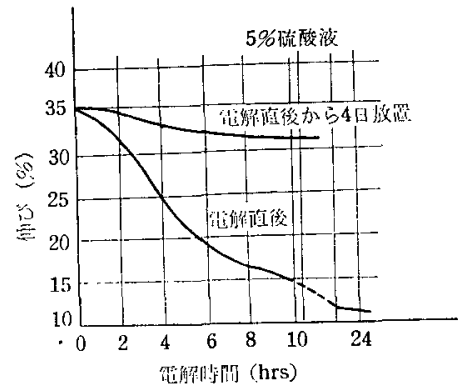

図一 9 水素添加による伸びの減少と放 置による回復 ${ }^{36)}$

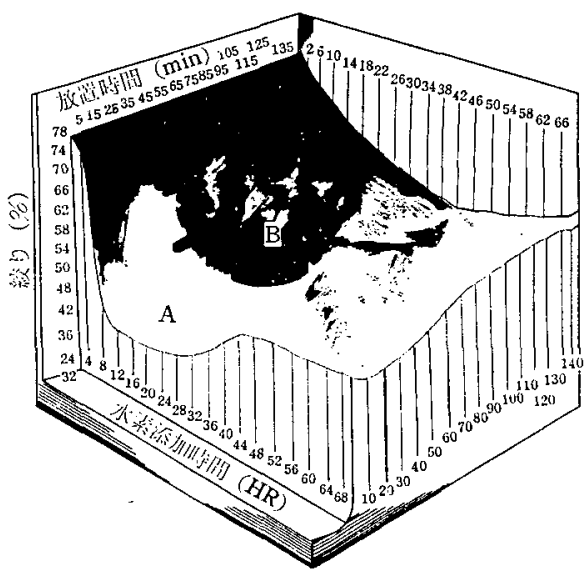

図一10 水素肪化に及ぼす水素添加時間放置時間の 影響15)

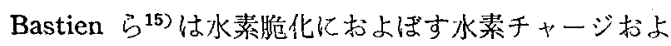
び放置時間の影響を园一100ごとく示している。水菜添 加特間が $8 \sim 32$ 時間で絞りは最小になる. また放置時間 10〜90分程度の亡ころに凹型の絞りの最小区域が生じて いるが，とれらの現象の説明については明らかでない.

なお時効による回復は板厚怔厚いほど遅い。鋼製ロー ルなど室温ではかなりの年月を要するので，熱妈理で水 素除去を行なう。

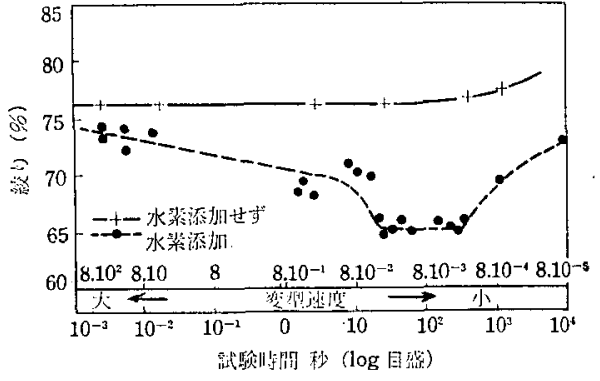

図一11 水素脆化に対する変形歪速度の影響12)*

\section{III-2 歪速度の影輩}

水菜脆化を調べるには歪速度の影響を知るととが重要 である. 軟鋼については BaIdwin と Brown が盜度と 関連して歪速度の水素脆化への影響を詳細に検討してい る47)、すなわち水菜脆化は低歪速度程起りやすく，歪速 度が増すとかえって起りにくい6,36,40)。乙の現象は高張 力鉦のほうが軟鋁より顕著であった 約5000 10,000 in/in/min 以上の速度の衝抙試験では水 素脆化が見られないと述べている の示した試跧速度の影響である12)。これによっても変形 速度の小さいある限られた（範围試験時間約100秒）てで 水素脆性が最も顥著である。

以上の理由で一般に偩撃試験では水素脆化の影響が顕 れにくい6,46). むっ上も対象とする鋼材，熱処理および 上くに試験温度で多少の相達がある。而る場合変らない 上報告されているが，注意深い研究ではやや衝撃値が低

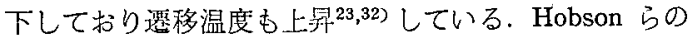
史験37を綜合すると， $-50^{\circ} \mathrm{C}$ 以下のかなり低温でい 之衝擊值に対する低合金鋼の水素脆化の影響を省略でき

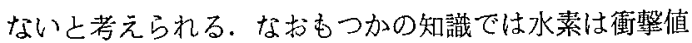
に本当に影響があるのかよくはわかっていない.

\section{III-3 温度の影響}

鋼の水素脆化は一般に低温においては消隇する ${ }^{6,15)}$. ある実験では $-110^{\circ} \mathrm{C}$ 以下で消失するという ${ }^{23,48)}$. ま

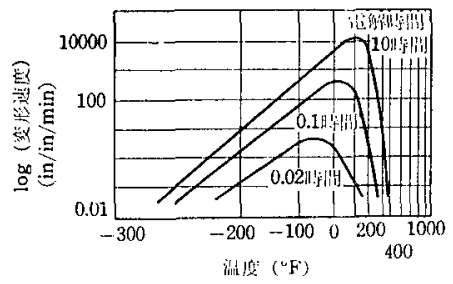

図一12 軟鋼の水菜脆化の限界 (Toh and Baldwin $)^{47)}$ 水素は電解により あたえられた $\left(4 \% \mathrm{H}_{2} \mathrm{SO}_{4}\right.$ 水溶液， 電流密度 $0.15 \mathrm{~A} / \mathrm{cm}^{2}$ )

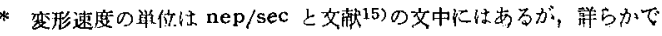
ない。 


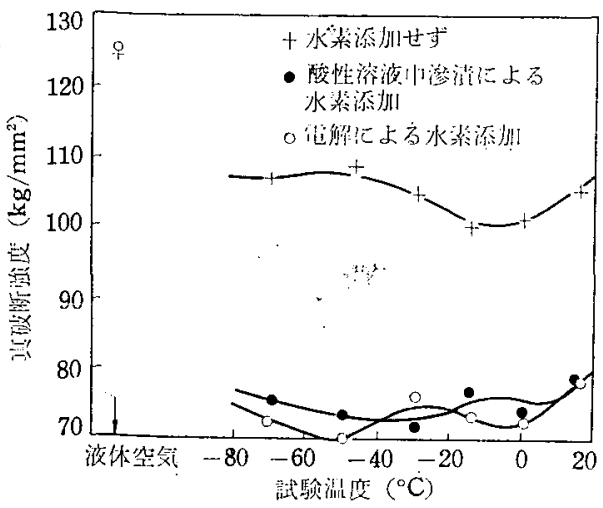

図一13 水素脆化に対する温度の影響12)

た水素脆化を起す温度範囲は $-100^{\circ} \mathrm{C} \sim 100^{\circ} \mathrm{C}$ で, 最 も激しい温度は室温よりやや低い温度ともいゔ。. Bald-

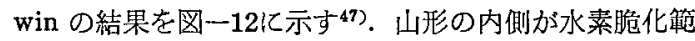
团で，低温あるいは高温では脆性が消失する傾向が知ら れる.な抱一12はまた脆化の温度範囲が变形速度にむ

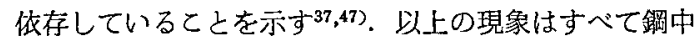
の拡散速度により説明される。

Bastien 上Azou は温度の影響は可逆的で $-160^{\circ} \mathrm{C}$ で脆化しないものを $-110^{\circ} \mathrm{C}$ に上げると再び脆化した ことを示している $\left.{ }^{37}, 48\right)$. 同じく塑性領域の水素脆化に対 する温度の影響を図一13に示している ${ }^{12)}$. 水菜添加した ものは室温では明らか嘪破壊強さが低下するが，たと えば液体空気のような低温では水菜が内部に残留してい るにもかかわらず水素脆化していない，屯ち万ん室温に 戾すと前述のごとくまた脆化する。

水菜添加した䤱 は脆性破壊の破壊 様式が変化する. Ludwik と Shevandin $^{12)}$ は鍽の引 張応力曲線汇対す る温度の影響を図 -14のごとくあら わし, 破壇様式を 脆性破䁁, 準脆性 破壊および延性破 罗汾分類してい る. 図-15は極軟

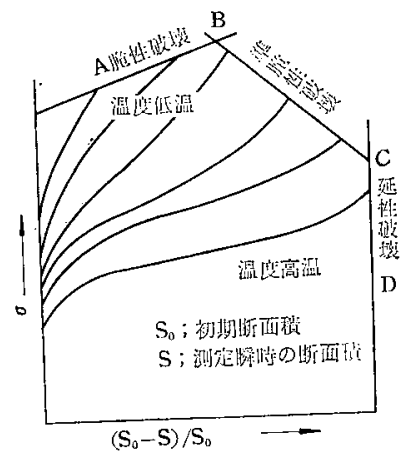

图-14 真応力 $(a)$ 上変形比济 $\left(S_{0}-S\right) / S_{0}$ の関係 ${ }^{22}$
鋼を水素添加したものとしないものについて $-110^{\circ} \mathrm{C}$ $+15^{\circ} \mathrm{C}$ の温度艒囲䎲ついて図一 14 の関係を確めた結果 である，室温付近で延性破壊を示した試験片が，水案添 加により辟開破塤 (Cleavage fracture) に移行する.

Hobson b Hewitt 屯引張試験における温度の影響を

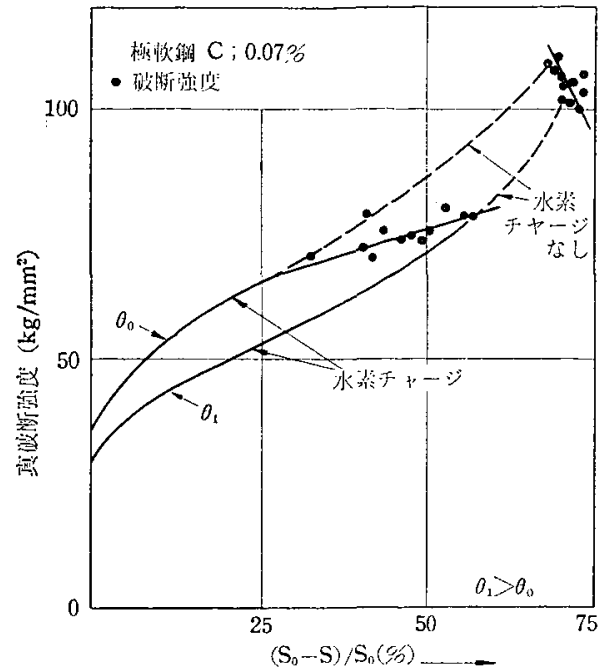

図一15 真破断強度之変形比較の関係（極軟䤫に水 菜を陰極電解法によりチャージ) $\theta_{0}, \theta_{1}$ は試駼温度

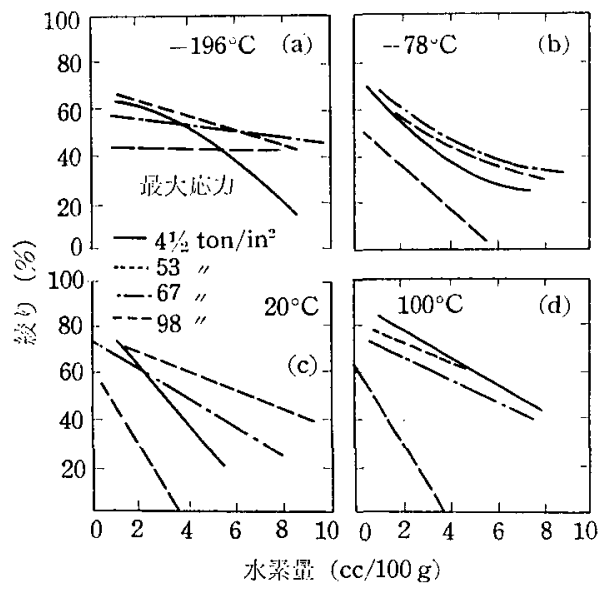

図一-16 3\% Cr-Mo 鋼の水素脃化に及ばす試験温度 の影響, 熱処理で鋼を種々の最大応力を持つ ように調節したむの (Hobson, Hewitt) ${ }^{49}$

しらべた ${ }^{37,49}$. 図一16はその結果を示したもので温度が 上るとと屯に獬化現象は顕著で, $-196^{\circ} \mathrm{C}$ では水素量が 增しても脆化はほとんど見られていない，

\section{III-4 波労強度}

水素添加が鋼の疲労強度に及ばす影響については実験 が困難なためかあまり見られない．0.3\% C，3\% Cr-Mo 低合金鋼に水素を $0.8 \sim 7 \mathrm{cc} / 100 \mathrm{~g}$ 添加後 20 分以内に疲 労試鈳が完了できるようにして行なったとてろ, 絽返数 に2/3の隇少が示されだ7)。また Vibrans と Hofman は 鋼中の溶解水素が疲労強さに加なりの影響を与えること を示している，因一 17 に軟鋼 $\mathrm{CK} 22(0.20 \% \mathrm{C}, 0.29 \% \mathrm{Si}$, $0.58 \% \mathrm{Mn}) に つ い て ゙{ }^{50-52)}$ の結果の 1 例 ${ }^{512}$ を示した. 水 


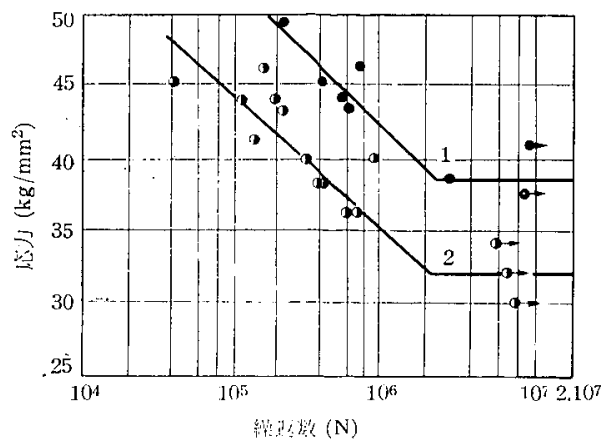

図一17 水装量の異なる烧準, 加工した鋼 CK 22 の室温の疲労試験結果 (Hofmann ら) ${ }^{51)}$

1. 水素添加せず， $10 \%$ 加工 水素量 $<0.1 \mathrm{~cm}^{3} / 100 \mathrm{~g}$

2. 水素添加, $10 \%$ 加工 水素量 $10 \mathrm{~cm}^{3} / 100 \mathrm{~g}$

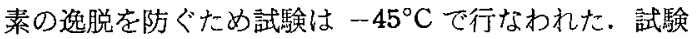
前10\%の引張歪を与えた場合はとくに耐久限の減少が著 しかった. との悪影響は非可逆的で, 疲労試験前に脱水 素をしても回復しない. 水素添加後塑性変形を与えた母 材はもち万ん年溶着鋼の場合は溶接のままでもやはり回 復が見られない50)。これらの原因としては溶着鋼の場合 はミクロ割れやミクロフイッシャなどの微小な欠宿ある いは，溶接後の鸰却に伴ない溶着鋼中に局部的な塑性変 形が50起るためと考えられている.

\section{III-5 予歪時効そのほかの影響}

水素船化は姏理により著しく変る。一般に予歪冷間加 工や硬化処理を受りると水素脆化の感受性は大となる ${ }^{15}$, 53). 加工度 $8 \%$ 以上で顕著な水菜脆化が示されている ${ }^{12)}$ 一般に水索吸収は泠間加工とともに增加する。しかしな がら絞りは冷間加工度20〜30\%で最小になり，それ以上 ではかえって增加する54)。な拆縮応力下では水素脆化 は起らないととが一般敒られている。

電解により水素添加直後予歪を与えた試験片はその後 の放置によって脆化が回復しない，すなわち非可逆的で あるてとが多数の鋼について知られている16,36,40-42)。 外力により発生した元り帯に水菜が搪散し，それ以上の えりを妨げることが予想される. またこの場合低歪量で あミク口的な小きれつの発生も認められている ${ }^{36)}$. 軟鋁 では水素添加直後12１8\%の丕を加えると衝撃値を低下 するとのことである38. なおててで注意すべきととはて の水素添加直後の予昰による時効現象がこのような単 純な変化ではなく，むしろ上記と全く相反する結果が Troiano らにより示されているととである. てれらの点 については水素脆化の機構と直接関連するので, その項

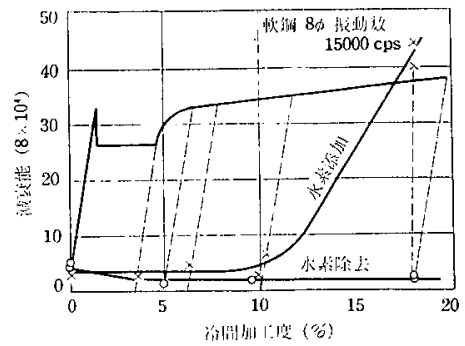

図一18 内部摩擦（減衰能）におよぼす 冷間加工の影響 (Bastien Azou) ${ }^{12}$

で詳しく述べる。

また Lesilie とRickett ${ }^{15)}$ によれば，最初の負荷 を $A$, 除荷再試験時の新しい降伏を生ずるに要する荷重 を $B$ として歪時効の程度を $\frac{B-A}{A} \times 100(\%)$ であらわ すと5.3歪後室温で70時間時勃したむのの歪時効度が10.1 \%の屯のが水索添加後同一の処理を行なうことにより $5.2 \%$ に減少した。すなわち水素添加により再降伏に要す る応力は減少している.

Bastien ら ${ }^{12}$ は弾性変形領域での水素脆化の傾向を内 部摩擦で求めた，種々の冷間加工をした焼なまし軟鋼に 水素添加し, 応力值 $20 \mathrm{~g} / \mathrm{mm}^{2}$ を越えない荷重での試 験結果を図一18に示した。加工度約 $8 \%$ まで減衰能に変 化なく，10\%以上で增加した．18\%加工したものも室温 で放置すると元に送り減衰能も可逆的であることがわか る.

そのほか高压水素ガス中に保持された鋼材の脆化につ いて屯調べられている50,54,55) Vibrans ${ }^{50)}$ は溶接部の銀点 内の水素压 100 1000 気圧に達するとの計算結果をむと に, この程度の水素圧が鋼の機械的性質におよぼす影響 をしらべている、結果の1例を表一2に示した．アルゴ

表一2 鋼 CK 22 (焼ならし) の引張強さ，破断時の伸 びおよび较りに対する外部ガス仕力の影響50)

\begin{tabular}{|c|c|c|c|c|c|}
\hline ガ & 窔 & 水 & アルゴン & $\mid \begin{array}{c}\text { 我素十 } \\
0.05 \% \text { 酸甞 }\end{array}$ & $\begin{array}{l}\text { 水 素十 } \\
2 \% \text { 䜹 }\end{array}$ \\
\hline 理力（気仼） & 1 & $100^{-}$ & 100 & 100 & 100 \\
\hline $\begin{array}{l}\text { 引娠 強 } \\
\left(\mathrm{kg} / \mathrm{mm}^{2}\right)\end{array}$ & 49.8 & 46.6 & 48.4 & 46.5 & 49.8 \\
\hline 破断 時o & 35.2 & 26.2 & 35.7 & 35.8 & 27.3 \\
\hline 较 り(\%) & 63.8 & 30.0 & 62.7 & 58.7 & 35.6 \\
\hline
\end{tabular}

ン中では脆化しないことから，水菜ガス中では塑性変形 により連続的に活性化された面に水素原子が吸着溶解 し，割れは伝播するとして Petch らの理論を裹付して いる. この寒験ではとくに水素に $\mathrm{O}_{2}$ を 0.1 または 0.05 \%加えると脆化が止ることが興味深い. $\mathrm{N}_{2}$ 屯同様の効 果があるが影響はやや小さい。なお Hofman らによれ ば50)，とのように外部汃ら加圧で水菜を加えるととの利 
点は，压力と水素ガス純度の影響を他の変形速度や温度 の影響と同様に独立して変化できるととである．彼らは この方法により溶接における気孔や割れに対する水素の 影響の基碟実験を進めてきた。

\section{III-6 組織およひ熱処理の影豐}

水素脆化は組織によりその脆化の程度を異にする。一 般にマルテンサイト，烇むどしマルテンサイト，粗い層 状パーライト，細い層状パーライト，粒状パーライトの 順に低下する ${ }^{15)}$.

Bastien は $\mathrm{Cr}-\mathrm{Mo}$ 銤 $(0.26 \% \mathrm{C}, 1.2 \% \mathrm{Cr}, 0.30 \% \mathrm{Mo})$ について調べた結果次のように述べている地). パーライ ト，ベイナイトおよび微細な球状ソルバイトなど高温で 生成するような熱力学的平衡状態 (thermodynamic equilibrium state）に近い組織は一般に水素の作用に対す る感受性が小さい，いっほうラルデンサイト組織は最む 脆化を受けやすい，同一の実験条件では微細な球状ソル バイトはマルテンサイトに比べて水素の昅着度が少なく 水菜の拡散性が高い。

表一 3 は上記の $\mathrm{Cr}-\mathrm{Mo}$ 鍮についての水素脆化感受性 と組織の関係を示したものである年，表中の脆化指数 I は次式で求的られ。.

$$
I(\%)=\frac{\Sigma U . C-\Sigma C}{\Sigma U . C} \times 100
$$

ここで $\Sigma U . C$; 水素添加しない場合の絞り

$$
\Sigma C \text {; 水素添扣した場合の絞り }
$$

表一 3 から弾性限が大きい組織结ど水素脆化さ扎やす

\begin{tabular}{|c|c|c|}
\hline 絊 & 弹性限界 $\left(\mathrm{kg} / \mathrm{m} \mathrm{m}^{2}\right) \mid$ & 脆化指数 (\%) \\
\hline 球状パーライト a) & 54.0 & 31 b) \\
\hline 并状パーライト & 51.0 & 39 \\
\hline 粗精層状パーライト & 35.5 & 42 \\
\hline マルテンサイト & 122.0 & 100 \\
\hline 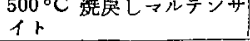 & 103.0 & 94 \\
\hline
\end{tabular}

表一3 脆化指数におよぼす組織の影響12)

a) $875^{\circ} \mathrm{C} 30$ 分オーステナイト化油姑入 $750^{\circ} \mathrm{C} 15$ 分 3 段棵状化処理 $680^{\circ} \mathrm{C} 30$ 分球状化処理

b) 曼近フランス鉄鋼界で開発された鋼确で delayed tempering

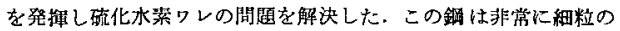
球状ハーテイトが均一下分相している。脆化指数 $15 \%$ \%すのる出 来ている。

いととがわかる. パーライト組織でも熱処理により脆化 指数は変化している.すなわちセメンタイトの形（球状 とか層状）が重要なととが推测される，水素の吸収には セメンタイトの形状のほうが量より影響が大きい56).た とえば層状のむのは球状のむのより水素の拡散が妨げら れ，したがって放出水素量が少ないことが認められてい る.

図一 19 は $0.10 \% \mathrm{C}, 2 \sim 2.5 \% \mathrm{Cr}, 0.9 \sim 1 \% \mathrm{Mo}, 0.25 \% \mathrm{~V}$

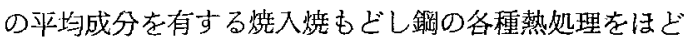

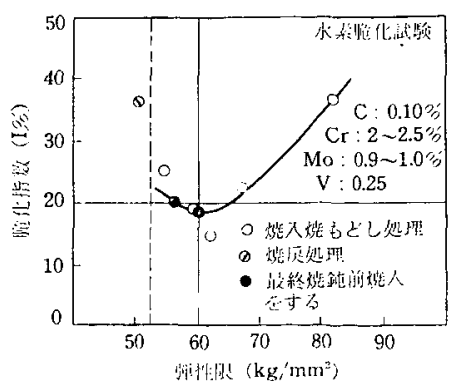

図一19 水素脆化に戈よばす弾性限の影 響 (Bastien) ${ }^{12,15)}$

こしたものについて弾性限と脆化指数の関係を求めたも のである ${ }^{12,15)}$. 弾性限の上早ととむに脆化指数が増加し ていることは前述と同じであるが，図中のQ印で示した ように烧焉よ゙しマルデンイトや焼もどしベイナイトの ような高温で烧もどしたものはかえって脆化しやすいと とは興味樑い.

垡一4 は炭素鋼（SC 30）について熱処理による組織 亡脆化度を示したものでる ${ }^{33)}$ ，水熦入した場合脆化度 がかえって小さくなっているが，乙れは焼入効果が大き く，はじめから脆化しているため，水素による影響が他 の延性の大きい組織はよ゙あらわれなかったためと解釉さ れる。

表一 4 炭素鎝（SC 30）の熱処理による組織と水素脆

\begin{tabular}{|c|c|c|c|}
\hline 熱 処 理 & 溨 & 脆化度 $(\%)$ & 水素量 $(\mathrm{cc} / 100 \mathrm{~g})$ \\
\hline 蚴 & マルテンサイト & 7.2 & 0.3 \\
\hline マルテンハー & $\div 1+1+$ & 38.5 & 7.5 \\
\hline 兟なむし & $\begin{array}{l}\text { ハニライト, } \\
\text { フェライト }\end{array}$ & 42.8 & 6 \\
\hline
\end{tabular}
化の関係 $\left.(山 \text { 根 })^{33}\right)$

以上は主として延性について調べたすのであるが，水 素添加による衝撃值の変化に対して屯組織の影響は重要 である. Hobson と Sykes ${ }^{19}$ は次のような契験を示して いる.すなわち $690^{\circ} \mathrm{C}$ で恒温処理後の低合金鋼 (1/4\% $31 / 4 \% \mathrm{Cr}-\mathrm{Mo})$ に $300^{\circ} \mathrm{C}$ の高压で $4 \frac{1}{2} \mathrm{cc}$ の水素を添加

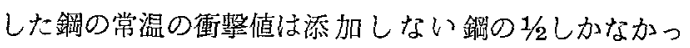
た.ととろが同じ鎡を $930^{\circ} \mathrm{C}$ で空冷硬化後 $710^{\circ} \mathrm{C}$ で 4 時間焼もどしした場合は $20 \sim 100^{\circ} \mathrm{C}$ の試験で10〜15\% の娍少に此まった。

Stout ら ${ }^{20)}$ の奏験でも $1 / 4 \% \mathrm{C}-1 \% \mathrm{Mn}-\mathrm{Mo}$ 低合金鎙に $5 \mathrm{cc} / 100 \mathrm{~g}$ の水萦添加した場合空冷試片では兴移温度が 約 $15^{\circ} \mathrm{C}$ 上卓したが，㹸入したものには変化がまったく なかった、いっぱう Mn-Ti 高張力鋼の場合は $6 \mathrm{cc} / 100 \mathrm{~g}$ の水素添加で遷移温度も衝整值もいづれも差が生じなか った。すなわち以上の研究汃ら熱処理による組織变化の

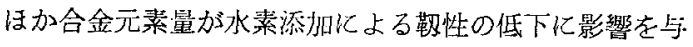


えるととがわかる．なお熱処理する と, 組織が変ると同時们吸収水素量も 变化するので組織に吸収水菜量の多塞 の果してごちらが㖉性に影響を与えて いるものか判然としない，捄そらくこ れらの両者がきいているものと考えら れる。

な枋同じマルテンサイト組織でも， 高炭素マルテンサイトは低炭菜マルテ ンサイトより水素胎化感受性が著しく 高い. Kelly と Nutting はこの相違 を電子顕微鏡により観察した結果, 高

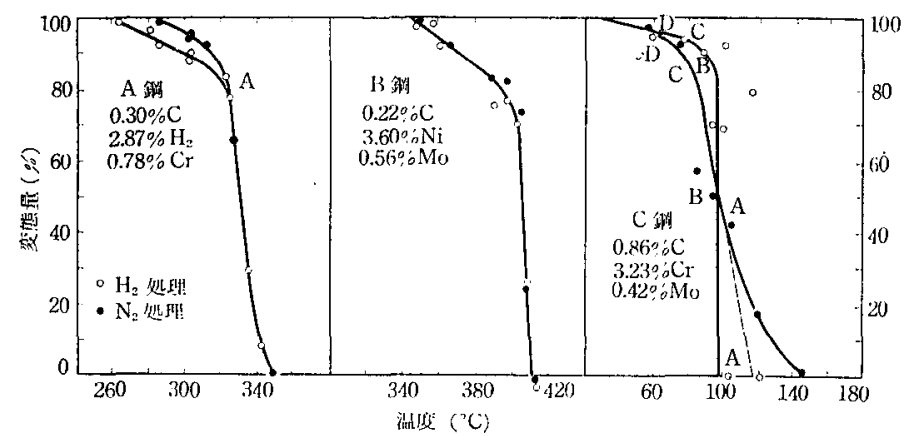

図一213種の鋼のマルテンサイト変態に及ぼす水素の影響 (R. Kumar) ${ }^{62)}$

一マルテンサイト変態に影響を扎よぼすかどうかは興味 あるところである60-63). Cottrell の実験によれば 0.19\% C-Mn-Mo 高張力鋭の溶接熱サイクル再現試験片の $M_{f}$ 温度が $14 \mathrm{cc} / 100 \mathrm{~g}$ の水素添加により約 $240^{\circ} \mathrm{C}$ から 180 ${ }^{\circ} \mathrm{C}$ まて低下したが，ただし $M_{s}$ 温度には变化がなかっ た. いっぽう Vaughan 上 de Morton ${ }^{16)}$ は軟鋼溶着金 属の $M_{f}$ 温度には 8 12 cc/100 $\mathrm{g}$ 程度の水素の影響は なかったと述へている. Kumar と Quarrell'62) は水素の 変態への影響はC 量の増加とともに著しくなり，水素は マルテンサイト形成の芽（embryo）になるととを主張 している，結局変態に及ぼす影響は鋼の成分により著し く異なると考えられる．図一21はその結果の代表例を示 したものである.すなわち Kumar ら ${ }^{62}$ すこれらの結果 加ら 4 7 cc/100 $\mathrm{g}$ の水素添加による㴔化の傾向を次の 3 㮔の型にわけて観察している.

i) $0.3 \% \mathrm{C}-3 \sim 4 \% \mathrm{Ni}-\mathrm{Mo}$ や快削 $13 \mathrm{Cr}$ 鋪などでは $M_{f}$ 温度を $20 \sim 40^{\circ} \mathrm{C}$ 程度低下させた。

ii) $\quad 0.2 \sim 0.3 \% \mathrm{C}-3 \% \mathrm{Cr}-\mathrm{Mo}$ Ð $0.8 \% \mathrm{C}-4.25 \mathrm{Ni}-\mathrm{Cr}-\mathrm{Mo}$ 鋼なよ゙は変態に影響がなかった。

iii) $0.57 \sim 0.86 \% \mathrm{C}-3 \% \mathrm{Cr}-\mathrm{Mo}$ 銅なよ゙では $M_{s}$ 温度 は $50^{\circ} \mathrm{C}$ 低下すると同時に $M_{f}$ が上昇し，変態は爆発 的に進行した。

Gladman らは最近これらの結論に対して次のような 反駁をしている ${ }^{63)}$. Kumar らの結果には水素好理の高 温でオーステナイト化している間に脱炭した影響が結果 にあらわれたので，さらに厳密な奏験方法によれば，ベ イナイト恒鼬変態やさらには連続冷却におけるマルテン サイト变態に刘してむ水素の明らかな影響は見られない としている.

また Andrew ら た $3 \% \mathrm{Ni}-\mathrm{Cr}-\mathrm{Mo}$ 䥡を水素処理した場合, 恒温変態の下 におけるパーライト域では变態を遅らせるが，下部べイ ナイト域では替伏期間を減ずることにより抽かに変態 を加速するととを示している。 


\section{参考 文 献}

1) H.J. Read, "Hydrogen Embrittlement in Metal Firishing". Chapter 3 "The Behavior of Hydrogen in Iron and Steel," Reinhold Pub. Corp., (1961) p. 46 80

2）西村，福原，大谷，“溶接構造用高張力鎆おょびその溶接部の硫化 物腐食制㧈”，新三淩重工技報 Vol. 4，(1962)，No. 3p. 2 24

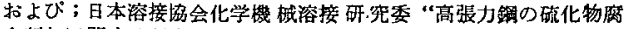

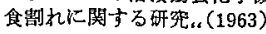

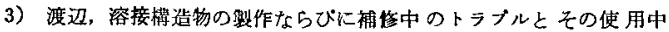

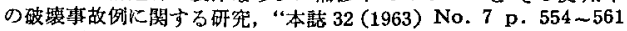
および (1963) No. 8 p. $645 \sim 651$

4) P.E. Bell, "Bibiography on the Effects of Hydrogen Embrittlement of Metals 1952 to present", LAMS-2283 June (1959) Los Alamos Sci. Lab. Rep.

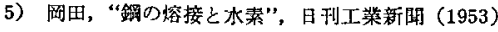

6) P. Cotterill, "The Hydrogen Embrittlement of Meta. Is", Prog. in Mat. Sci. Vol. 91 (1961), 205 301

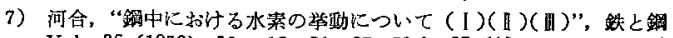
Vol. 36 (1950), No. 12, 21 25, Vol. 37 (1951), No. 1, 23 $\sim 29$, Vol. 38 (1952), No. 1, 9 17.

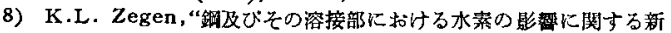
ᄂい知識 (1)(II)(歌), 本誌 Vol. 29 (1960), No. 6, 442 45 0 ; Vol. 29 (1960), No. 7, 509 516

9) C.A. Zapffe anc C.E. Sims, "Hydrogen in Weld Metal", The Welding J., 19 (1940) $377 \mathrm{~s} \sim 395 \mathrm{~s}$

10) C.L.M. Cottrell, "Hydrogen-Barrier to welding Process, "British W.J., Vol. 1, (1954), No. 4, 167 176

11) A.L. Schaeffler, H.C. Campbell and H. Thielsch, "Hydrogen in Mild Steel Weld Metal," Welding J., 31 (1952), No. 6, 283-s 309-s

12) P.G. Bastien; Hydrogen in Welding, British W.J., (1960), No. 9, 546 557

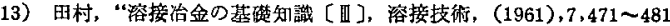

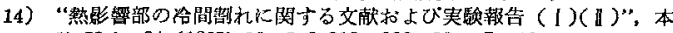
誌 Vol. 24 (1955) No.5,6 219 222; No. 7, $281 \sim 284$

15) P.G. Bastien, "The Phenomena of Cracking and Fracture of Steel in the Presence of Hydrogen. Corrosion under Stress in the Presence of Moist Hydrogen Sulfi. de", Phys. Met. of Stress Corr. Fracture, Interscience Pub., (1959)

16) H.G. Vaughan and M.E. de Morton, "Hydrogen Embrittlement of Steel and it's Relation to Weld Metal Cracking", Brit. W.J., (1957), No. 1, 40 61

17) N. Christensen, "The Role of Hydrogen in Arc Welding with Coated Electrodes", Welding J., 40 (1961), No. $4,145-\mathrm{s} \sim 154-\mathrm{s}$

18) N. Christensen, K, Gjermundsen and R. Rose "Hydrogen in Mild steel Weld Deposits", Brit, W.J., (1958), No. $6,272 \sim 281$

19) J.D. Hobson and C. Sykes; J. Iron Steel Inst., Vol. 169, (1951) 209

20) R.D. Stout, L.J. McGead, C.P. Sun, J.F. Libsch, and G.E. Doan, "Effect of Welding on Ductility and Notch Sensitivity of some Ship Steels", Welding J., 26 (1947), No. $6,335-\mathrm{s} \sim 357-\mathrm{s}$

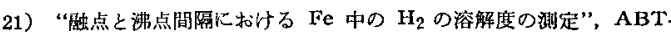
OMAT CBAP $16[1]$ p. $36 \sim 43,1963$

22) M.G. Fontana and J. Chipman, "Equibrium, in the Reaction of Hydrogen with Ferrous oxide in Liquid Iron at $1600^{\circ} \mathrm{C} "$ ", Trans. A.S.M., Vol. 24, (1936) 313 336

23) F.de Kazinczy, "A Theory of Hydrogen of Hydrogen Embrittlement", J. of I.S.I. 185, (1954), May. 85 92

24) C.A. Zaffe, "Concept of the Hydrogen. Potential in Steam-Metal Reaction", Trans, A.S.M., 40, (1948) 315 354

25) D.P. Smith, "Hydrogen in Metals", The Univ. of Ch. icago Press. Chicago 111., (1948)

26) J. Plusbuellec and et al ; Compt, rend., 248 (1959), 181 $6 \sim 1819$

27) J.D. Hobson, "The Diffusion of Hydrogen in Steel at Temperature of $-78^{\circ}$ to $200^{\circ} \mathrm{C}$ ", J. of I.S.I. 189, (1958), Aug. 315-321

28) Dekker ; Solid Physics, p.23 (1961) コロサ社・橋口・神山草

29) A.M. Adair and R.E. Hook, "The Appearance and Return of a Hydrogen Yield Point in Iron", Acta Met, 10 (1962) No. $8741 \sim 745$
30) B.A. Bilby and J. Hewitt, "Hydrogen in Steel-the St ability of Micro Cracks", Acta Met., 10 (1962) No. 6, 5 $87 \sim 600$

31) J. Plusquellec and et al., Compt rend., 246 (1958) 3268 $\sim 3631$

32）美馬，办田，“炭慗鋼の水素脃化と内部磨擦”，鉄と銅，43（1957） No. $2132 \sim 137$

33）山根，“洗き入れ岸素鋼の水菜脆化について”，鉄と銅，49（1963） No. 7, 1003 1008

34) L.C. Wiener, and M.Gemsamer., Acta Mət., 5 (1957) 692

35) T.S. Kè and P.T. Young; Scientia Sinica, Vol. 3, No. 3 (1954) 261

36）菊田, “乹銅の水素脆化”, 冾金研等委資料 No. WM-22-62

37) P.D. Blake and W.I. Pumphrey "Effect of Hydorogen in Wrought steel and in Ferrous Weld Metal", Brit, W.J., 6 (1959) No. 5, $211 \sim 224$

38) P. Bastien and P. Azou, "Effect of Hydrogen on the Deformation and Fracture of Iron and Steel in Simple Tension", Proc. of the First World Met. Cong., ASM (191) $535 \sim 552$

39) G.V. Karpenko and R.I. Kripyakevich, Phys, Met, and Metallog., 8 (1959) $77 \sim 80$

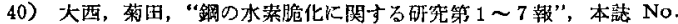
$8.9,224-330 ; 25$ (1956) No. 3,$148 ; 25$ (1956) No. 11,62 $3 \sim 628 ; 27$ (1958) No. 3, 154 155;28 (1959) No. 3, 164 166

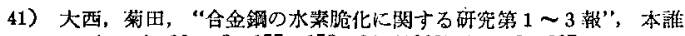
30 (1961) No. 3, 177 178; 31 (1962) No. 3, 237

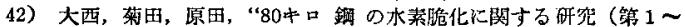
2 刺)", 本詰 32 (1963) No. $3,275 \sim 276$

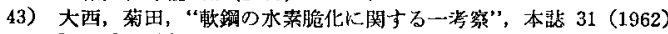
No. 3,236

44) F. de Kazinczy, Acta Met., 7 (1959) 706 708

45) J. Plusquellec, P. Azou and P. Bastien, Compt. rend., 246 (1958) 3454 $\sim 3457$

46) C.L. M. Cottrell, "Weldability of B-Mo Steel in Rela" tion to Heat Affected Zone", Brit, W.J., 1 (1954), No. $7,315 \sim 321$

47) J. T. Brown and W.M. Baldwin J., "Hydrogen Embrittlement of Steels", J. Met., Vol. 6 (1954), 298 304

48) P. Bastien and P. Azou; Comptes Rendues, Vol. 229, (1949) 549

49) J.D. Hobson and J. Hewitt; J. Iron Steel Inst., Vol. 173 (1953), 130

50) W. Hof mann, "Some New Aspects Concerning the Hydrogen Embrittlement of Welded Steel", I.I.W. Doc. IX-319-1962

51) W. Hofmann and G. Vibrans, "Die Wirkung von Wa sserstoff auf die Dauerschwingfestigkeit von geschwei. Bten Stahl", Sch. u. Schneid., 12 (1960) 95 101

52) W. Hof mann and G. Vibrans, Rêv Met., 57 (1960) 88 90

53) R.M. Hudson, J. Riedy and G.L. Stragand, Corrosion. $16(1960)$ p. $97 \sim 101$

54) R.H. Cavett and H.C. Van Ness, "Embrittlement of Steel by High-Pressure Hydroen Gas", Welding J., 42 (1963), No. 7 316-s $\sim 319-\mathrm{s}$

55) W. Hofmann u, W, Rauls, A rch. Eisenhuttenw., 32 (1961) Heft. 3, p. $169 \sim 171$

56) F. Erdmann-Jemitzer u. H. Sabath; Arch. Eisenhuitt. enwes, 28 (1957) Heft 5/8, 345 353

57) F. Watkinson, R.G. Baker and H.F. Tremlet, "Hyd rogen Embrittlement in Relation to the Heat-affected Zone Microstrure of Steel", Brit W.J., Vol. 9 (1963) 54 $\sim 62$

58) J.T. Berry and R.C. Allan, "A Study of Cracking in Low-Alloy Steel Welded Joints", Welded J. 39 (1960) No. $3,105 \mathrm{~s} \sim 116 \mathrm{~s}$

59) S. Besnord and J. Talbot ; Rev. Mét., 56 (1959) 163 170

60) C.L.M. Cottrell, "Transformation Temp. of Alloy St. eels Related to Weldability with Low.Hydrogen Electrode", Brit. W.J., 1 (1954) No. 9, 409 412

61) J.H. Andrew et al., "Hydrogen and Transformation Characteristics in Steel," J. Iron Steel Inst, (1947) No. $6,208 \sim 253$

62) R. Kumar and A.G. Quarrell, "The Effect of Hydrogen upon Martensite Formation in Low-alloy Steels", J. Iron Steel Inst., 187 (1957) $195 \sim 204$

63) T. Gladman, P. Moore and A.G. Quarrell, "The Effects of Hydrogen on Transformation in Alloy Steel," J. Iron Steel Inst., (1962), No. 7, 527 534 